\title{
CRITICAL FACTORS RESPONSIBLE FOR TIME OVERRUNS IN NIGERIA BUILDING CONSTRUCTION INDUSTRY
}

\section{Oluyemi-Ayibiowu Bamitale Dorcas ${ }^{1}$ and Omolayo John Oluwakayode ${ }^{2}$}

${ }^{1}$ Department of Civil Engineering, School of Engineering and Engineering Technology, The Federal University of Technology, Akure. E-mail: bayibiowu@yahoo.com

${ }^{2}$ Department of Civil Engineering, School of Engineering and Engineering Technology, The Federal University of Technology, Akure. E-mail: omolayo_oluwakayode@yahoo.com

\section{Cite this article:}

Oluyemi-Ayibiowu B.D., Omolayo J.O. (2022), Critical Factors Responsible for Time Overruns in Nigeria Building Construction Industry. International Journal of Mechanical and Civil Engineering 4(1), 22-33. DOI: 10.52589/IJMCEIQYK7V9W

\section{Manuscript History}

Received: 1 Dec 2021

Accepted: 29 Dec 2021

Published: 6 Jan 2022

Copyright $(92020$ The Author(s). This is an Open Access article distributed under the terms of Creative Commons AttributionNonCommercial-NoDerivatives 4.0 International (CC BY-NC-ND $4.0)$, which permits anyone to share, use, reproduce and redistribute in any medium, provided the original author and source are credited.
ABSTRACT: Time overruns are major problems facing the Nigerian construction industry. It's of high concern to those who are involved in the construction industry. This study was carried out to identify the major causes of time overruns in the Nigerian building construction industry, by means of a literature review and a questionnaire survey. A total of twenty (20) time overrun causative factors were obtained from the literature. The questionnaire survey was distributed to randomly selected respondents from a combination of clients, consultants, contractors, site engineers, project managers and sub-contractors. In all, one hundred and forty-one (141) questionnaires were distributed to randomly selected respondents (clients, consultants, contractors, site-engineers, project-managers and subcontractors), one hundred and thirty-two (132) questionnaires were returned out of which three (3) questionnaires were found incomplete and invalid. Only one hundred and twenty-nine (129) questionnaires were found consistent and valid for use in this research. Relative Importance Index (RII) and Severity Index were used to carry out a ranking analysis. Based on the data received, the five (5) most severe factors influencing project handling overtime in Nigeria construction industries are Inaccurate evaluation of projects time/duration (91.9\%), Risk and uncertainty associated with projects $(91.6 \%)$, Complexity of works $(87.6 \%)$, Weak regulation and control $(86.8 \%)$ and Lack of financial power with severity $(86.3 \%)$.

KEYWORDS: Construction Industry, Relative Importance Index, Time overruns 


\section{INTRODUCTION}

The construction industry is almost as old as nature itself and unlike many manufacturing industries, it is concerned mostly with one-off projects. The efficient construction industry is a prerequisite to effective national development since building, civil and industrial engineering works are usually a major contribution to Gross fixed capital formation, Gross Domestic Product (GDP) and National employment. This is very important in the socio-economic growth of a nation. The successful completion of construction projects within the time frame, budget allocation and expected quality and durability are, therefore, fundamentally crucial (Aftab, 2013).

Serious concerns have been expressed about construction projects which have not been delivered in various parts of the country after huge financial mobilizations have been made. Nigeria experienced frequent failures and project abandonment due to ineffective management techniques. However, projects are seldom completed on time. Unfortunately, most of the projects failed to achieve project completion with the estimated cost. Time is also a top visible parameter since contractors would be expected to deliver the project, within a specified time and cost based on contract agreements and terms (Anuja, and Parag, 2015). Construction industries in Nigeria are facing a lot of challenges in managing construction projects in the areas of time management. Completion of projects in time within the budget, and with desired quality is a basic requirement that is seldom achieved in the construction industry. This has become a worldwide problem, leading to project abandonment and huge economic loss. Time is a sensitive factor in contracting and controlling project duration and cost. In Nigeria, it has been shown that out of 3,407 projects, only 24 were completed in time, while 1,517 were delayed and 1812 were abandoned (Amu, and Adesanya, 2011). There is a need to identify and evaluate the most severe factors influencing project duration.

The research is aimed at determining the most severe factors influencing project duration for efficient and effective project time management in the Nigerian construction industry. The specific objectives are to: identify the factors influencing project duration and to rank the factors. The study is limited to projects within Nigeria, using Lagos, Abuja and Portharcourt metropolis of Nigeria as case study areas. It is limited to the identification of the factors influencing project time; and ranking of the most severe factors influencing the time of construction projects. The relationship that exists between project duration and other parameters such as roles of the project team (respondents); academic qualification; level of experience (in years); type of project; project funding; and past project challenges will be determined. Target respondents for this study are the principal actors in the construction industry namely: owner/client, consultant, contractor, site-engineers, project-managers, and sub-contractors. The study involved: a collection of site reports on the time of projects on some large construction sites; data collection from the selected project sites with the aid of structured and unstructured questionnaires; personal interviews; analysis of data. 


\section{LITERATURE/THEORETICAL UNDERPINNING}

Achieving completion of construction projects on time is a basic requirement. However, projects are seldom completed on time. Construction delay is generally acknowledged as the most common, costly, complex and risky problem encountered in construction projects. The overriding importance of time for both the owner and the contractor has made it a source of frequent disputes and claims leading to lawsuits (Ahmed et al., 2003). Delays do not always result from a single catastrophic event. They frequently develop slowly during the course of work. Delays can cause substantial damages to an owner. The successful execution of construction projects and keeping them within the estimated cost and prescribed schedules depend on a methodology that requires sound engineering judgment. A study showed that the Vietnamese government has acknowledged this issue as a serious concern, especially with government-related funded projects (Le-Hoai et al., 2008).

\section{Previous Research on Factors Influencing Project Delay}

There are many factors that contribute to the causes of delays in construction projects. Delays occur in every construction project and the magnitude of these delays varies considerably from project to project. It is essential to define the actual causes of delay in order to minimize and avoid delay in any construction project. A number of studies have been carried out worldwide to determine the causes of delays in construction projects.

Yogeswaran et al. (1998) investigated 67 civil engineering projects in Hong Kong and found at least $15 \%-20 \%$ of time overrun was due to inclement weather. They concluded that Time Delay can be due to one or more reasons including problems of financing and payment for completed works.

Al-Momani (2000) conducted a survey on 130 public projects in Jordan and found delays occurred in $106(82 \%)$ of the projects.

Chan and Kumaraswamy (2002) conducted a survey to determine and evaluate the relative importance of the significant factors affecting construction delays. They analysed and ranked the main factors affecting the construction time, and classified them into two groups: the role of the parties in the local construction industry and the type of projects. Based on their survey results, they indicated that the five major causes of delays were: poor site management and supervision, unforeseen ground conditions, low speed of decision making involving all project teams, client-initiated variations and necessary variations of works.

Frimpong et al. (2003) found that 33 (70\%) out of 47 projects in Ghana were delayed.

Alwi and Hampson (2003) had a similar study on the causes of delays in building construction projects. The delay factors were grouped into six major groups. The results showed that the top five most important delay causes were: slow decision making, which was ranked the highest, followed by design changes, poor distribution of labour, inappropriate construction methods, and poor coordination among project participants.

Omoregie and Radford (2006) reported that the minimum average percentage escalation period of projects in Nigeria was found to be $18.8 \%$. 
Assaf and Al-Hejji (2006) reported that in Saudi Arabia, 70\% of projects faced time delay with an average time delay of $10 \%$ to $30 \%$ of the original duration of the project.

Sambasivan and Soon (2007) have identified the 10 most important causes of as: contractor's improper planning, contractor's poor site management, inadequate contractor experience, inadequate client's finance and payments for completed work, problems with subcontractors, material shortage, labour supply, equipment availability and failure, lack of communication between parties, and mistakes during the construction stage.

Alaghbari et al. (2007) similarly carried out a study and identified a list of 31 delay factors. The major delay factors from their survey results were: financial difficulties and economic problems, contractor financial problems, late supervision and slowness in making decisions, material shortages, poor site management, construction mistakes and defective work, delay in delivery of materials to the site and lack of consultant's experience.

El-Razek et al. (2008) carried out a study to determine the causes of delays in building construction projects. Based on the survey results, the top five delay causes were: financing by the contractor during construction, delays in contractor's payment by the owner, design changes by the owner or his agent during construction, partial payments during construction and non-utilization of professional construction management.

Sweis et al. (2008) in a similar study carried out in Egypt, also concluded that financial difficulties faced by the contractor and too many change orders by the owner are the leading causes of construction delay.

Tumi et al. (2009) studied the delays in construction projects in Libya. They concluded that the main causes of delay in construction projects were improper planning, followed by lack of effective communication, material shortage, design errors and financial problem.

Endut et al. (2009) studied the time performance of 359 projects (301 new constructions while 58 refurbishment projects) in Malaysia. Of these 301 were public projects and 51 were private projects. The study found that only $18.2 \%$ of the public sector projects and $29.45 \%$ of privatesector projects had $0 \%$ time deviation (no delays) while the average percentage of time overrun for other projects was $49.71 \%$.

Zujo et al. (2010) conducted similar research in Bosnia and Herzegovina on 177 projects and found that the contracted date was not met in $51.40 \%$ of the projects.

Ibrahim et al. (2010) studied the construction industry in Malaysia, it was discovered that the construction industry is facing the same critical problem of time overrun

Abdullah (2010) reported that more than $90 \%$ of large MARA construction projects experienced delay since 1984 .

Fugar and Agyakwah-Baah (2010) also studied the causes of delays in building construction projects in Ghana. They identified 32 possible causes of delay and further categorized them into nine major groups. Based on their analysis, they concluded that the delay in honouring certificates, underestimation of the costs of projects, underestimation of the complexity of projects, difficulty in accessing bank credit, poor supervision, underestimation of time for completion of projects by contractors, material shortage, poor professional management, 
fluctuation of prices/rising cost of materials and poor site management were found to be the top ten most important factors affecting the construction time.

Amu and Adesanya (2011) investigated 3,407 projects in Nigeria, out of which only 24 projects were completed on time, while 1517 were delayed and 1812 were abandoned.

\section{METHODOLOGY}

\section{Study Areas}

Three locations (study areas) were selected in Nigeria for this research. These are Abuja, Lagos and Portharcourt. The choice of locations was based on commercial viability, social status, economic considerations and area accessibility which provide opportunities for diverse industries like construction, consulting, manufacturing, agriculture, telecom, marketing, legal, health and technological advancement.

\section{Research Methodology}

In this research, questionnaires were administered to collect necessary data. With the aid of the latest version of the SPSS software, all collected data were analyzed to carry out: descriptive analysis of respondents' characteristics, ranking and severity analysis, reliability statistics and Pearson correlation. A total of One hundred and twenty-nine (129) experienced personnel involved in handling construction projects, responded to the questionnaires in Lagos, Abuja and Portharcourt, as a representative of the entire Nigeria construction sites.

This research methodology was carried out under literature review, interviews, questionnaires survey and secondary data collection. These methods acted as supplements to each other which made the data collection more comprehensive, meaningful and valid. Basically, the literature review focused on gaining a better understanding of time performance and causative factors affecting its overrun in construction projects. These factors were analyzed in conformance to represent the problems of time overrun in prevailing construction industries in Nigeria through administered questionnaires and interviewing experienced personnel involved in handling construction projects. This revealed the perception of owner/client, consultant, contractor, siteengineers, project-managers, and sub-contractors towards the factors causing time overrun. Gathered data were ranked using the Relative Importance Index (R.I.I) method and statistical tools in order to draw the conclusion in determining the current situation of the time overrun problem and factors contributing to these overrun.

\section{Population Sampling and Questionaire Design}

The entire population size $(\mathrm{N})$ and total representative sample (n) for this research were determined using the simple random sampling (SRS) method. Simple random sampling is a method in which members or items of the population can only be selected one at a time for inclusion in the sample. The sample size (n) for each study area was calculated using: 
$n=n^{\prime} /\left[1+\left(n^{\prime} / N\right)\right]$

Where:

$\mathbf{N}=$ total number of population

$\mathbf{n}=$ sample size from finite population

$\mathbf{n}^{\prime}=$ sample size from infinite population $=\mathbf{S}^{2} / \mathbf{V}^{2}$;

where:

$\mathbf{S}^{2}$ is the variance of the population elements and

$\mathbf{V}$ is a standard error of sampling population.

Usually $\mathbf{S}=0.5$ and $\mathbf{V}=0.06$; (Assaf et al., 2001 \& Moore et al., 2003).

\section{Relative Importance Index (R.I.I) Analysis}

The relative importance index method (rii) was used to determine the respondents' perception of the level of importance of the highway project delay factors and their severity level. the formula used for calculating the relative importance index (rii) is as follows:

$$
\text { relative important index }(\text { r.i.i })=\frac{5 n_{n_{5}}+4_{n_{4}}+3_{n_{3}}+2_{n_{2}}+1_{n_{1}}}{5 n}
$$

where:
$\mathrm{n}_{5} \quad$ is the number of respondents for strongly influence
$\mathrm{n}_{4} \quad$ is the number of respondents for little influence
$\mathrm{n}_{3} \quad$ is the number of respondents for may or may not influence.
$\mathrm{n}_{2} \quad$ is the number of respondents for no influence.
$\mathrm{n}_{1} \quad$ is the number of respondents for virtually no influence.
$\mathrm{n} \quad$ is the total number of respondents.
a is the highest weight (as shown in table 1, where a is 5)
$\mathrm{n} \quad$ is the variable expressing frequency of $i$
$\mathrm{a}_{\mathrm{i}} \quad$ is the constant expressing weight given to $i$ th response: $i=1,2,3,4,5$.

The item with the highest RII value was ranked first (1) the next (2) and so on.

Interpretation of the RII values is as follows:

$\mathrm{RII}<0.60$, the item is assessed to have a low rating

$0.60 \leq \mathrm{RII}<0.80$, the item is assessed to have a high rating.

$\mathrm{RII} \geq 0.80$, the item is assessed to have a very high rating. 
Table 1: Linkert Scale showing ranking and weights

\begin{tabular}{|l|c|c|c|c|c|}
\hline Item & $\begin{array}{c}\text { Strongly } \\
\text { Disagree }\end{array}$ & Disagree & $\begin{array}{c}\text { Neither Agree } \\
\text { nor Disagree }\end{array}$ & Agree & $\begin{array}{c}\text { Strongly } \\
\text { Agree }\end{array}$ \\
\hline Description & $\begin{array}{c}\text { Not very } \\
\text { Important }\end{array}$ & $\begin{array}{c}\text { Not } \\
\text { Important }\end{array}$ & $\begin{array}{c}\text { Moderately } \\
\text { Important }\end{array}$ & Important & $\begin{array}{c}\text { Very } \\
\text { Important }\end{array}$ \\
\hline Scale & 1 & 2 & 3 & 4 & 5 \\
\hline
\end{tabular}

The Severity Index (I) was calculated to interpret the degree of severity effect of the identified factors influencing time on building construction projects using Lagos, Abuja and Portharcourt as case study areas in Nigeria. The categorizations reflected the scale of the respondents' answers to the questionnaire. The severity index of a category was the average severity indices of all its related factors.

This index was calculated as follows:

Severity Index $(\mathbf{I})=\frac{\sum_{i=1}^{5}\left(a_{i}\right)\left(n_{i}\right)}{A \times N} \times 100 \%$

i.e. Severity Index $(\mathbf{I})=$ R. I. $I \times 100 \%$

The severity index was categorized into five levels:

- $0-49 \%$ was categorized as none severe;

- 50-69\% was categorized as fairly severe;

- $70-74 \%$ was categorized as moderately severe;

- $75-79 \%$ was categorized as severe; and

- $80-100 \%$ was categorized as most severe.

The most severe independent factors for a time as the dependent variable under investigation were selected as the most relative important factors influencing apportioned research objectives.

\section{RESULTS/FINDINGS}

The results presented are characteristics of respondents to questionnaires distributed, ranking and severity analysis and correlation results.

\section{Characteristics of Respondents}

Table 2: Questionnaire Distribution and Responses from the selected study areas

\begin{tabular}{|l|l|l|l|l|}
\hline & Abuja & Lagos & Portharcourt & TOTAL \\
\hline Number Distributed & 48 & 60 & 33 & $\mathbf{1 4 1}$ \\
\hline Number of Responses & 44 & 54 & 31 & $\mathbf{1 2 9}$ \\
\hline Percentage of Responses (\%) & $\mathbf{9 1 . 6 7}$ & $\mathbf{9 0 . 0 0}$ & $\mathbf{9 3 . 9 4}$ & $\mathbf{9 1 . 4 9}$ \\
\hline
\end{tabular}

$\%$ Responses $=($ Number of responses/Number Distributed $) \mathbf{X} 100 \%$ 
Table 3: Summary of Characteristics of Respondents

\begin{tabular}{|c|c|c|c|c|}
\hline & Category & Classification & Frequency & Percent (\%) \\
\hline \multirow[t]{7}{*}{1.} & \multirow{7}{*}{$\begin{array}{l}\text { Roles/Position of } \\
\text { Respondents }\end{array}$} & Owners & 10 & 7.75 \\
\hline & & Consultant & 22 & 17.05 \\
\hline & & Contractor & 40 & 31.01 \\
\hline & & Site Engineer & 25 & 19.38 \\
\hline & & Project Manager & 11 & 8.53 \\
\hline & & Sub-contractor & 21 & 16.28 \\
\hline & & Total & 129 & 100 \\
\hline \multirow[t]{6}{*}{2.} & \multirow{6}{*}{$\begin{array}{l}\text { Respondents' } \\
\text { Academic } \\
\text { Qualification }\end{array}$} & O.N.D & 0 & 0 \\
\hline & & H.N.D & 26 & 20.16 \\
\hline & & B.Sc/B.Tech & 40 & 31.01 \\
\hline & & P.G.D & 25 & 19.38 \\
\hline & & M.Sc/M.Tech & 32 & 24.81 \\
\hline & & Ph.D & 6 & 4.65 \\
\hline \multirow[t]{6}{*}{3.} & \multirow{6}{*}{$\begin{array}{l}\text { Respondents' } \\
\text { Level of } \\
\text { Experience in } \\
\text { Construction } \\
\text { Project }\end{array}$} & 1 year to 2 years & 0 & 0 \\
\hline & & 2 years to 5 years & 13 & 10.08 \\
\hline & & 5 years to 10 years & 20 & 15.50 \\
\hline & & 10 years to 15 years & 43 & 33.33 \\
\hline & & 15 years and above & 53 & 41.09 \\
\hline & & Total & 129 & 100 \\
\hline \multirow[t]{7}{*}{4.} & \multirow{7}{*}{$\begin{array}{l}\text { Respondent's } \\
\text { Type of Project }\end{array}$} & Residential & 9 & 6.98 \\
\hline & & Non-Residential & 51 & 39.53 \\
\hline & & Public utility & 19 & 14.73 \\
\hline & & Civil works & 18 & 13.95 \\
\hline & & Commercial/ special trade & 32 & 24.81 \\
\hline & & $\begin{array}{l}\text { Others that were not } \\
\text { specified }\end{array}$ & 0 & 0 \\
\hline & & Total & 129 & 100 \\
\hline \multirow[t]{4}{*}{5.} & \multirow{4}{*}{$\begin{array}{l}\text { Type of Project } \\
\text { Funding }\end{array}$} & Public & 42 & 32.56 \\
\hline & & Private & 65 & 50.39 \\
\hline & & Joint & 22 & 17.05 \\
\hline & & Total & 129 & 100 \\
\hline \multirow[t]{7}{*}{6.} & \multirow{7}{*}{$\begin{array}{l}\text { Respondent's } \\
\text { Previous Project } \\
\text { Challenges }\end{array}$} & Abandoned project (1) & 41 & 31.78 \\
\hline & & $\begin{array}{l}\text { Delivered behind schedule } \\
\text { (2) }\end{array}$ & 52 & 40.31 \\
\hline & & $\begin{array}{l}\text { Experienced cost over-run } \\
\text { (3) }\end{array}$ & 31 & 24.03 \\
\hline & & Reworked/berated (4) & 5 & 3.88 \\
\hline & & has no challenge & 0 & 0 \\
\hline & & no project experience & 0 & 0 \\
\hline & & Total & 129 & 100 \\
\hline
\end{tabular}




\section{Ranking Analysis (Relative Importance Index and Severity Index) Result}

From TABLE 4, the five (5) most severe factors influencing project handing over time in Nigeria construction industries are: Inaccurate evaluation of projects time/duration (91.9\%), Risk and uncertainty associated with projects (91.6\%), Complexity of works (87.6\%), Weak regulation and control $(86.8 \%)$ and Lack of financial power with severity $(86.3 \%)$.

Table 4: Factors Influencing Time Arranged according to Ranking

\begin{tabular}{|c|c|c|c|c|c|}
\hline \multirow[b]{2}{*}{$\begin{array}{l}\text { FACTORS INFLUENCING TIME } \\
\text { AFTER RANKED }\end{array}$} & \multirow[b]{2}{*}{ ID } & \multicolumn{4}{|c|}{ AVERAGE } \\
\hline & & MEAN & RII & $\begin{array}{l}\text { SEVERIT } \\
\underset{(\%)}{Y}\end{array}$ & RANK \\
\hline $\begin{array}{l}\text { Inaccurate evaluation of projects } \\
\text { time/duration }\end{array}$ & TF15 & 4.59 & 0.919 & 91.9 & 1 \\
\hline $\begin{array}{l}\text { Risk and uncertainty associated with } \\
\text { projects }\end{array}$ & TF2 & 4.58 & 0.916 & 91.6 & 2 \\
\hline Complexity of works & TF13 & 4.38 & 0.876 & 87.6 & 3 \\
\hline Weak regulation and control & TF18 & 4.34 & 0.868 & 86.8 & 4 \\
\hline Lack of financial power & TF8 & 4.32 & 0.863 & 86.3 & 5 \\
\hline Indiscriminate Change in design/works & TF1 & 3.97 & 0.795 & 79.5 & 6 \\
\hline Dependency on imported materials & TF6 & 3.86 & 0.769 & 76.9 & 7 \\
\hline Unpredictable weather conditions & TF5 & 3.82 & 0.764 & 76.4 & 8 \\
\hline Project fraud and corruption & TF19 & 3.77 & 0.755 & 75.5 & 9 \\
\hline Low skilled manpower & TF4 & 3.76 & 0.743 & 74.3 & 10 \\
\hline Delay in payment of completed works & TF9 & 3.66 & 0.739 & 73.9 & 11 \\
\hline Inflation of prices (variations) & TF10 & 3.57 & 0.736 & 73.6 & 12 \\
\hline Fluctuation of currency/exchange rate & TF20 & 3.43 & 0.702 & 70.2 & 13 \\
\hline Unstable government policies & TF16 & 3.42 & 0.702 & 70.2 & 14 \\
\hline $\begin{array}{l}\text { Lack of proper training and experience } \\
\text { of Project Manager (PM) }\end{array}$ & TF3 & 3.31 & 0.697 & 69.7 & 15 \\
\hline $\begin{array}{l}\text { Disagreement on interpretation of } \\
\text { contract documentation and } \\
\text { specification }\end{array}$ & TF11 & 3.20 & 0.584 & 58.4 & 16 \\
\hline Conflict between project parties & TF12 & 2.91 & 0.58 & 58.0 & 17 \\
\hline Unstable interest rate & TF17 & 2.88 & 0.561 & 56.1 & 18 \\
\hline $\begin{array}{l}\text { Non performance of subcontractors } \\
\text { and nominated suppliers }\end{array}$ & TF14 & 2.78 & 0.547 & 54.7 & 19 \\
\hline $\begin{array}{l}\text { Use of inappropriate software for cost } \\
\text { estimation }\end{array}$ & TF7 & 2.23 & 0.446 & 44.6 & 20 \\
\hline
\end{tabular}


Table 5: Inter-Item Correlation Matrix

\begin{tabular}{|c|c|c|c|c|c|c|c|c|}
\hline & & Q1 & Q2 & Q3 & Q4 & Q5 & Q6 & TF \\
\hline \multirow{7}{*}{$\begin{array}{l}\text { Pearson } \\
\text { correlation }\end{array}$} & Q1 & 1.000 & 0.39 & 0.62 & 0.74 & 0.16 & 0.35 & 0.51 \\
\hline & Q2 & 0.39 & 1.000 & 0.31 & 0.15 & 0.09 & 0.43 & 0.81 \\
\hline & Q3 & 0.62 & 0.31 & 1.000 & 0.24 & 0.20 & 0.94 & 0.841 \\
\hline & Q4 & 0.74 & 0.15 & 0.24 & 1.000 & 0.91 & 0.78 & 0.51 \\
\hline & Q5 & 0.16 & 0.09 & 0.20 & 0.91 & 1.000 & 0.19 & 0.89 \\
\hline & Q6 & 0.35 & 0.43 & 0.94 & 0.78 & 0.19 & 1.000 & 0.53 \\
\hline & TF & 0.51 & 0.81 & 0.841 & 0.51 & 0.89 & 0.53 & 1.000 \\
\hline \multirow{8}{*}{$\begin{array}{c}\text { Sig. } \\
\text { (1-tailed) }\end{array}$} & & Q1 & Q2 & Q3 & Q4 & Q5 & Q6 & $\mathbf{T F}$ \\
\hline & Q1 &. & .000 & .000 & .000 & .000 & .001 & .000 \\
\hline & Q2 & .000 & . & .000 & .002 & .000 & .000 & .005 \\
\hline & Q3 & .000 & .000 & . & .000 & $1.223 \mathrm{E}-5$ & .000 & .000 \\
\hline & Q4 & .000 & .002 & .000 & . & .000 & .000 & .000 \\
\hline & Q5 & .000 & .000 & $\begin{array}{c}1.223 \mathrm{E}- \\
5\end{array}$ & .000 & . & .000 & .000 \\
\hline & Q6 & .001 & .000 & .000 & .000 & .000 & . & .000 \\
\hline & TF & .000 & .005 & .000 & .000 & .000 & .000 & . \\
\hline $\mathrm{N}$ & \multicolumn{8}{|c|}{129} \\
\hline
\end{tabular}

Where:

$\mathrm{Q} 1$ = Roles of project team (respondents); Q2= Academic qualification; Q3= Level of experience (in years); Q4= Type of project; Q5= Project funding; Q6= Past project challenges; $\mathrm{TF}=$ Time-factor.

\section{CONCLUSION}

From the study, it was concluded that the most severe factors affecting project duration in Nigerian construction industries are: Inaccurate evaluation of projects time/duration (91.9\%), Risk and uncertainty associated with projects (91.6\%), Complexity of works (87.6\%), Weak regulation and control (86.8\%) and Lack of financial power with severity (86.3\%). According to the respondents, inaccurate evaluation of projects time/duration has been a serious cause of time overrun in Nigeria construction industry. 


\section{REFERENCES}

Abdullah, M.R., Aziz, A.A.A. and Rahman, I.A. (2010). 'Causes of delay and its effects in large MARA construction project'. International Journal of Integrated Engineering (Issue on Mechanical, Materials and Manufacturing Engineering). 10(2): 58-66.

Aftab, H.M., Jamilus M.H. and Ismail, A.R. (2013). "The Way Forward in Sustainable Construction; Issues and Challenges", International Journal of Advances in Applied Sciences (IJAAS); Vol.2, No.1; ISSN: 2252-8814; 3-42.

Ahmed, S.M., Azhar, S., Kappagantula, P. and Gollapudi, D. (2003). 'Delays in Construction: A Brief Study of the Florida Construction Industry'. ASC Proc. the 39th Annual Conference Clemson Univ. South Carolina, 257-266.

Alaghbari, W., Kadir, M.R.A., Salim, A. and Ernawati (2007). 'The significant factors causing the delay of building construction projects in Malaysia'. Eng. Const. Arch. Manage. 14(2): 192-206.

Al-Momani, A. (2000). "Construction delay: a quantitative analysis". International Journal of Project Management, 18 (1), 51-59.

Alwi, S. and Hampson, K. (2003). "Identifying the Important causes of delays in building construction projects". Proc. 9th East Asia-Pacific Conference on Structural Engineering and Construction, 1-6, Bali, Indonesia. http://eprints.qut.edu.au/4156/1/4156.pdf.

Amu, O.O. and Adesanya, D.A. (2011). 'Mathematical Expressions for Explaining Project Delays in Southwestern Nigeria', Singapore Journal of Scientific Research; Vol. 1(1), ISSN: 2010-006, Pp.59-67.

Anuja, R. and Parag, M. (2015). 'Effective Techniques in Cost Optimization of Construction Project', International Journal of Research in Engineering and Techology (IJRET); Volume 04, ISSN: 2319-1163 | ISSN: 2321-7308 Review, Pp.464. (Available @ http://www.ijret.org)

Assaf, A., Bubshait, A.A., Atiyah, S. and Al-Shahri, M. (2001). 'The Management of Construction Company Overhead Costs', International Journal of Project Management; Vol. 19; PII: S0263-7863 (00) 00011-9, Elsevier Science Ltd. and IPMA. Pp. 295-303.

Assaf, S.A. and Al-Hejji, S. (2006). "Causes of delay in large construction projects". International Journal of Project Management: 24(4), pp. 349-357.

Chan, D.W.M. and Kumaraswamy, M.M. (2002). 'Compressing construction durations: lessons learned from Hong Kong building projects'. International Journal for Project Management. 20(1): 23-35.

El-Razek, A.M.E., Bassioni, H.A. and Mobarak, A.M. (2008). 'Causes of Delay in Building Construction Projects in Egypt'. Journal for Construction Engineering and Management. 134 (11): 831-841.

Endut, Rohani, I., Akintoye, A. and Kelly, J. (2009). "Cost and time overruns of projects in Malaysia," Proceedings of the $2^{\text {nd }}$ Scottish Conference for Postgraduate Researchers of the Built and Natural Environment (PROBE), Glasgow Caledonian University. Rotterdam (Netherlands), pp. 243-252.

Frimpong, Y., Oluwoye, J. and Crawford, L. (2003). "Causes of delay and cost overruns in construction of groundwater projects in a developing country: Ghana as a case study". International Journal of Project Management, 21 (5), 321-326.

Fugar, F.D.K. and Agyakwah-Baah, A.B. (2010). 'Delays in Building Construction Projects in Ghana'. Australia Journal for Construction Management and Economics. 10 (1): 128-141. 
Ibrahim, A.R., Roy, M.H., Ahmed, Z. and Imtiaz, G. (2010). "An investigation of the status of the Malaysian construction industry". Benchmarking: An International Journal, 17(2), 294-308.

Le-Hoai, L., Lee, Y.D. and Lee, J.Y. (2008). 'Delay and Cost Overruns in Vietnam Large Construction Projects: A Comparison with Other Selected Countries'. KSCE Journal of Civil Engineering, 12(6), 367-377.

Mahmoud, M.A. (2012). 'A Construction Resources Management System for Gaza Strip Building Contractors'.

Moore, D., McCabe, G., Duckworth, W. and Sclove, S. (2003). 'The Practice of business statistics', Freeman, New York.

Omoregie, A. and Radford, D. (2006). 'Infrastructure Delays and Cost Escalation: Causes and Effects in Nigeria', Paper presented at the Proceeding of a sixth international postgraduate research conference.

Sambasivan, M. and Soon, Y.W. (2007). "Causes and Effects of delays in the Malaysian construction industry". International Journal of Project Management. 25(5): 517-526.

Sweis, G., Sweis, R., Abu Hammad, A., and Shboul, A. (2008). Delays in construction projects: the case of Jordan. International Journal of Project Management, 26(6), 665674.

Tumi, S.A.H., Omran, A. and Pakir, A.H.K. (2009). 'Causes of Delay in Construction Industry in Libya'. Proc. Int. Conf. Administration and Business, Univ. Bucharest, Romania, 14-15th November 2009. pp. 265-272.

Yogeswaran, K., Kumaraswamy, M. and Miller, D. (1998). "Claims for extension of time in civil engineering projects”. Construction Management and Economics, 16 (3), 283293.

Zujo, V., Car-Pusic, D. and Brkan-Vejzovic, A. (2010). 'Contracted price overrun as contracted construction time overrun function'. Technical Gazette, 17(1), 23-29. 